\title{
Effects of hypothyroidism and hyperthyroidism on hematological parameters in rats
}

\author{
Sinan KANDIR, Ercan KESKIN \\ Selçuk University, Faculty of Veterinary Medicine, Department of Physiology, Konya, Turkey.
}

\begin{abstract}
Summary: In this study, it was aimed to interpret the effects of hypothyroidism and hyperthyroidism on hematological parameters in rats. A total of 42 male Wistar rats were divided into 3 equally groups as euthyroid, hypothyroid, hyperthyroid. Hypothyroidism and hyperthyroidism were induced by 6-n-propyl-2-thiouracil (PTU; 0,05\%, w/v) and L-thyroxine (L-T4; 0,0012\%, w/v) received in drinking water, respectively. Blood samples were withdrawn from 7 rats of each group at the end of 3rd and 6th weeks for determination of the hematological parameters and serum hormone profiles. Among the 3rd week groups only percentage of monocyte was increased $(\mathrm{p}<0.05)$ in the hypothyroid group when compared to the euthyroid group. In the 6th week hypothyroid group, red blood cell (RBC) counts, hemoglobin $(\mathrm{Hb})$ concentration, hematocrit $(\mathrm{Hct})$ value and percentage $(\%)$ of red cell distribution width $(\mathrm{RDW})$ were lower $(\mathrm{p}<0.05)$ than the 6th week euthyroid and hyperthyroid groups. However, plateletcrit $(\mathrm{PCT}) \%$ was higher $(\mathrm{p}<0.05)$ in the 6 th week hypothyroid group compared to the 6th week euthyroid group. In the 6th week hyperthyroid group, mean corpuscular hemoglobin concentration (MCHC) and platelet (PLT) counts were lower $(\mathrm{p}<0.05)$ than the 6th week hypothyroid group. In the 6th week hyperthyroid group percentage of lymphocyte was decreased $(\mathrm{p}<0.05)$ and percentage of granulocyte was increased $(\mathrm{p}<0.05)$ when compared to the 6th week euthyroid group. In conclusion, elongation of the treatment duration with PTU and L-T4 could lead to changes on some hematological parameters. However, these values remained within physiological ranges.

Keywords: Propylthiouracil, rat hematology, red blood cells, thyroid status.
\end{abstract}

\section{Ratlarda hipotiroidizm ve hipertiroidizmin hematolojik parametreler üzerine etkileri}

Özet: $\mathrm{Bu}$ çalışmada, hipotiroidizm ve hipertiroidizmin ratların hematolojik parametreleri üzerine etkilerini yorumlamak amaçlanmıştır. Toplam 42 adet erkek Wistar rat, ötiroid, hipotiroid ve hipertiroid olarak 3 eşit gruba ayrıldı. Hipotiroidizm ve hipertiroidizm sırasıyla 6-n-propil-2-tiourasil (PTU; \% 0,05, w/v) ve L-tiroksin (T4; \% 0,0012, w/v) içme sularına katılarak gerçekleştirildi. Hematolojik parametrelerin ve serum hormon profillerinin belirlenmesi için her grupta 7 rattan, 3. ve 6. haftanın sonunda kan örnekleri toplandı. Üçüncü hafta grupları arasında, yalnızca hipotiroid grubunun monosit yüzdesi ötiroid grubuna kıyasla artt1 ( $<0.05)$. Altınc1 hafta hipotiroid grubunda, alyuvar (RBC) sayıs1, hemoglobin $(\mathrm{Hb})$ konsantrasyonu, hematokrit (Hct) yüzdesi ve alyuvar dağılım genişliği (RDW) yüzdesi, 6. hafta ötiroid ve hipertiroid grubuna nazaran düşüktü (p<0.05). Ancak, 6 . hafta hipotiroid grubundaki plateletkrit (PCT) yüzdesi, 6. hafta ötiroid grubuna kıyasla yüksekti $(\mathrm{p}<0.05)$. Altıncı hafta hipertiroid grubunda, ortalama alyuvar hemoglobin konsantrasyonu (MCHC) ve platelet (PLT) sayis1 6. hafta hipotiroid grubuna nazaran düşüktü $(\mathrm{p}<0.05)$. Altıncı hafta hipertiroid grubunda, 6. hafta ötiroid grubuna kıyasla lenfosit yüzdesi düşük $(\mathrm{p}<0.05)$ ve granülosit yüzdesi yüksekti $(p<0.05)$. Sonuç olarak, propiltiourasil (PTU) ve L-tiroksin (L-T4) uygulama sürelerinin uzaması bazı hematolojik parametrelerde değişimlere sebep olmaktadır. Buna rağmen, bu değerler fizyolojik sınırlar içerisinde kalmaktadır.

Anahtar sözcükler: Kırmızı kan hücreleri, propiltiyourasil, rat hematolojisi, tiroid bozukluğu.

\section{Introduction}

Thyroid hormones (THs) have crucial roles on cellular and neuronal development, bone maturation, growth, metabolism, modulation of intracellular protein trafficking and regulating production of red blood cells by genomic or non-genomic actions $(5,8,31,38)$. Plasma concentrations of THs are controlled by thyroid hormone axis which consist of paraventricular nucleus of the hypothalamus, anterior pituitary and thyroid gland. Whilst the main secretory product of the thyroid gland is L-thyroxine (L-T4), 3,5,3-L-tri-iodothyronine (T3) is the major bio-active form of THs (16). Propylthiouracil (6-npropyl-2-thiouracil; PTU), which is the antithyroid agent inhibits 5-deiodinase hence inactivates thyroid peroxidase (TPO) and blocks intrathyroidal and peripheral conversion of $\mathrm{T} 4$ to $\mathrm{T} 3(23,26)$. On one hand deficiency or absence of THs cause hypothyroidism, on the other hand abundance of THs cause hyperthyroidism. There are often initiated by autoimmune origin disorders which against the thyroid gland named as Hashimoto's disease and anti-thyroid stimulating hormone (TSH) receptor in the thyroid gland named as Graves' disease 
may cause of hypo- and hyperthyroidism, respectively $(15,30)$.

Thyroid hormone receptor (TR)- $\alpha$ and TR- $\beta$ are highly conserved nuclear receptors which are encoded by THRA (NR1A1) and THRB (NR1A2) genes $(11,36)$. The early findings issued that hematopoietic system may be influenced by different thyroid status in vitro (13) and in vivo (22). In addition to these data, in recent years studies on underlying molecular mechanisms of thyroid hormones associated with changes in hematopoiesis revealed that modifying in gene expressions of TRs affect hematopoietic progenitors in vivo (19). Through this knowledge it is well known that THs can modulate cell production in the bone marrow (20).

PTU and L-T4 have been widely used in drugs on different animals experimentally or to cure the thyroid disorders in medicine $(2,16,19,26)$. Therefore, we aimed to interpret the hematological parameters on experimentally induced hypothyroidism and hyperthyroidism in rats.

\section{Materials and Methods}

Animals: In this research, 12 week-old, healthy, 42 male Wistar Albino rats (300-350 g weight) were used. Two rats per cage were housed in $40 \times 20 \times 20 \mathrm{~cm}$ size polycarbonate cages. They were fed ad libitum with Nukleon ${ }^{\circledR}$ standart rat chow (Bil-Yem). Rats were kept in a room at a constant temperature $22 \pm 2^{\circ} \mathrm{C}$ with $\% 50$ relative humidity, 12 hour light/dark cycle period. All experimental procedure was approved by Selçuk University Experimental Medicine Research and Application Center Local Ethics Committee (Approval number: 2012-083).

Experimental design: The rats were randomly and equally divided into 3 groups; euthyroid, hypothyroid and hyperthyroid. Hypothyroidism and hyperthyroidism were induced by 6-n-propyl-2-thiouracil (PTU; Sigma, USA) $0,05 \%$ (weight per volume; w/v) and L-thyroxine (L-T4; Sigma, USA) 0,0012\% (w/v) concentrations which are added into daily prepared fresh drinking water, respectively in accordance to previous studies $(2,8,10$, 14). In the study, mean water consumption of each animal was calculated approximately $\sim 50 \mathrm{ml}$. So, each animal received $\sim 25 \mathrm{mg}$ PTU and $\sim 0,6 \mathrm{mg} \mathrm{L}-\mathrm{T} 4$ as orally.

The blood samples were withdrawn from 7 rats of each group at the end of 3rd and 6th weeks of the experiment by cardiac puncture from under deeply anesthetized animals with ketamine $(50 \mathrm{mg} / \mathrm{kg} / \mathrm{BW})$ and xylazine $(2.61 \mathrm{mg} / \mathrm{kg} / \mathrm{BW})$ combination and were collected into anticoagulant (EDTA) containing tubes to determinate hematological parameters and tubes for centrifugation ( $3000 \mathrm{x} \mathrm{g}$ for $5 \mathrm{~min}$ ) to observe hormonal profiles in serum.
Hematological parameters were assessed by automated blood cell counter (Mindray BC 2800, China) and TSH, total thyroxine (TT4) and free thyroxine (FT4) levels were determined by autoanalyser (ADVIA Centaur XP Immunoassay System, Siemens, USA).

Statistical analysis: Statistical analysis was performed with the SPSS 19.0 statistical package for Windows (SPSS, Inc., Chicago, IL, USA). Data were expressed as mean \pm standard error of the mean (SEM). One-way ANOVA followed by post hoc Duncan's multiple range test was performed to show the statistical significance among the groups in the same week and independent t-test was performed for determination between the weeks in the same groups. $\mathrm{P}<0.05$ was considered to be statistically significant.

\section{Results}

Thyroid hormones: As shown in Table 1, in the 3rd and 6th weeks serum TSH levels were increased $(\mathrm{p}<0.05)$ in hypothyroid and decreased $(\mathrm{p}<0.05)$ in hyperthyroid groups. On the contrary, TT4 and FT4 levels were decreased $(\mathrm{p}<0.05)$ in hypothyroid and increased $(p<0.05)$ in hyperthyroid groups when compared with euthyroid groups.

Hematological parameters: The hematological findings of euthyroid, hypothyroid and hyperthyroid groups are presented in Table 2.

In compared to different sampling times of the same groups, the red blood cell (RBC) counts were increased $(p<0.05)$ in the 6th week euthyroid group to compare with the $3 \mathrm{rd}$ week euthyroid group. Hb concentration and Hct value were decreased $(\mathrm{p}<0.05)$ in the 6th week hypothyroid group to compare with the 3rd week hypothyroid group. Platelet (PLT) counts were decreased $(p<0.05)$ in the 6 th week hyperthyroid group to compare is on to the 3rd week hyperthyroid group.

In comparison among parameters of the $3 \mathrm{rd}$ week groups there were no statistical difference, except percentage of monocyte which was increased $(p<0.05)$ in hypothyroid group when compared to the euthyroid group.

In the 6th week hypothyroid group, RBC counts, $\mathrm{Hb}$ concentration, Hct value and percentage $(\%)$ of red cell distribution width $(\mathrm{RDW})$ were lower $(\mathrm{p}<0.05)$ than the 6th week euthyroid and hyperthyroid groups. However, plateletcrit $(\mathrm{PCT}) \%$ was higher $(\mathrm{p}<0.05)$ in the 6th week hypothyroid group compared with the 6th week euthyroid group.

In the 6th week hyperthyroid group, mean corpuscular hemoglobin concentration (MCHC) and PLT counts were significantly lower $(p<0.05)$ than the 6 th week hypothyroid group. It was observed that percentage of lymphocyte was decreased and percentage of granulocyte was increased $(p<0.05)$ in the 6th week hyperthyroid group when compared to the 6th week euthyroid group. 
Table 1. TSH, TT4 and FT4 levels in all groups ( $\mathrm{n}=7$, mean \pm SEM, $\mathrm{p}<0.05)$.

Tablo 1. Grupların TSH, TT4, ve FT4 seviyeleri ( $\mathrm{n}=7$, ort $\pm \mathrm{SH})$.

\begin{tabular}{cccccccccc}
\cline { 2 - 9 } & \multicolumn{3}{c}{ TSH $\mu \mathrm{IU} / \mathrm{mL}$} & \multicolumn{3}{c}{ TT4 $\mu \mathrm{g} / \mathrm{dL}$} & \multicolumn{2}{c}{ FT4 ng/dL } \\
\hline $\mathrm{W}$ & Eu & Hypo & Hyper & Eu & Hypo & Hyper & Eu & Hypo & Hyper \\
\hline 3rd & $1.58 \pm 0.21^{\mathrm{b}}$ & $13.65 \pm 1.54^{\mathrm{a}}$ & $0.02 \pm 0.003^{\mathrm{c}}$ & $3.17 \pm 0,13^{\mathrm{b}}$ & $0.72 \pm 0,11^{\mathrm{c}}$ & $8.28 \pm 0.78^{* \mathrm{a}}$ & $0.95 \pm 0,04^{\mathrm{b}}$ & $0.25 \pm 0.003^{\mathrm{c}}$ & $2.89 \pm 0.25^{\mathrm{a}}$ \\
6th & $1.88 \pm 0.54^{\mathrm{b}}$ & $12.22 \pm 1.49^{\mathrm{a}}$ & $0.02 \pm 0.004^{\mathrm{c}}$ & $2.94 \pm 0,09^{\mathrm{b}}$ & $0.91 \pm 0,08^{\mathrm{c}}$ & $10.39 \pm 0.52^{* \mathrm{a}}$ & $0.93 \pm 0,03^{\mathrm{b}}$ & $0.33 \pm 0.003^{\mathrm{c}}$ & $3.41 \pm 0.21^{\mathrm{a}}$ \\
\hline
\end{tabular}

W: Weeks, Eu: Euthyroid, Hypo: Hypothyroid, Hyper: Hyperthyroid.

a,b,c: Different letters shown the statistical significance among the groups on the same weeks $(\mathrm{p}<0.05)$.

$(*)$ : Sign shown statistical significance among the weeks in the same groups $(\mathrm{p}<0.05)$.

W: Haftalar, Eu: Ötiroid, Hypo: Hipotiroid, Hyper: Hipertiroid.

a,b,c: Farklı harfler, aynı haftadaki gruplar arası farklılıkları göstermektedir $(\mathrm{p}<0.05)$.

$(*)$ : Sembol, aynı gruptaki haftalar arası farklılıkları göstermektedir $(\mathrm{p}<0.05)$.

Table 2. Hematological parameters in experimental groups ( $\mathrm{n}=7$, mean \pm SEM).

Tablo 2. Deney gruplarına ait hematolojik parametreler $(\mathrm{n}=7$, ort $\pm \mathrm{SH})$.

\begin{tabular}{|c|c|c|c|c|c|c|}
\hline \multirow{2}{*}{$\begin{array}{l}\text { Groups } \\
\text { Parameters /Weeks }\end{array}$} & \multicolumn{2}{|c|}{ Euthyroid } & \multicolumn{2}{|c|}{ Hypothyroid } & \multicolumn{2}{|c|}{ Hyperthyroid } \\
\hline & $3 \mathrm{rd}$ & 6th & $3 \mathrm{rd}$ & 6th & $3 \mathrm{rd}$ & 6th \\
\hline $\mathrm{RBC}\left(\mathrm{x} 10^{12} / \mathrm{L}\right)$ & $7.93 \pm 0.11^{*}$ & $8.54 \pm 0.19^{* a}$ & $8.10 \pm 0.24$ & $7.56 \pm 0.09^{b}$ & $8.43 \pm 0.16$ & $8.27 \pm 0.14^{\mathrm{a}}$ \\
\hline $\mathrm{Hb}(\mathrm{g} / \mathrm{dL})$ & $14.10 \pm 0.26$ & $14.70 \pm 0.41^{\mathrm{a}}$ & $14.09 \pm 0.35^{*}$ & $12.99 \pm 0.14^{* \mathrm{~b}}$ & $14.53 \pm 0.23$ & $14.20 \pm 0.25^{\mathrm{a}}$ \\
\hline Hematocrit (\%) & $45.73 \pm 0.83$ & $48.31 \pm 1.35^{\mathrm{a}}$ & $46.29 \pm 1.14^{*}$ & $42.34 \pm 0.59 *^{\mathrm{b}}$ & $47.71 \pm 0.89$ & $47.37 \pm 0.95^{\mathrm{a}}$ \\
\hline MCV (fL) & $57.76 \pm 0.55$ & $56.63 \pm 0.81$ & $57.24 \pm 0.74$ & $56.04 \pm 0.49$ & $56.66 \pm 0.72$ & $57.36 \pm 0.35$ \\
\hline $\mathrm{MCH}(\mathrm{pg})$ & $17.74 \pm 0.21$ & $17.17 \pm 0.21$ & $17.34 \pm 0.19$ & $17.14 \pm 0.19$ & $17.19 \pm 0.24$ & $17.13 \pm 0.12$ \\
\hline $\mathrm{MCHC}(\mathrm{g} / \mathrm{dl})$ & $30.79 \pm 0.14$ & $30.39 \pm 0.19^{\mathrm{ab}}$ & $30.39 \pm 0.11$ & $30.64 \pm 0.25^{\mathrm{a}}$ & $30.43 \pm 0.27$ & $29.96 \pm 0.17^{\mathrm{b}}$ \\
\hline RDW (\%) & $11.26 \pm 0.29$ & $11.56 \pm 0.18^{\mathrm{a}}$ & $11.27 \pm 0.31$ & $10.53 \pm 0.21^{\mathrm{b}}$ & $11.70 \pm 0.32$ & $12.16 \pm 0.33^{\mathrm{a}}$ \\
\hline $\operatorname{PLT}\left(x 10^{9} / \mathrm{L}\right)$ & $589.43 \pm 58.99$ & $530.29 \pm 56.93^{\mathrm{ab}}$ & $640.29 \pm 47.72$ & $625.29 \pm 14.46^{\mathrm{a}}$ & $624.14 \pm 49.01 *$ & $493.43 \pm 35.19 * \mathrm{~b}$ \\
\hline MPV fL & $6.63 \pm 0.12$ & $6.76 \pm 0.14$ & $6.59 \pm 0.07$ & $6.66 \pm 0.11$ & $6.66 \pm 0.12$ & $6.90 \pm 0.12$ \\
\hline PDW (\%) & $15.06 \pm 0.08$ & $15.09 \pm 0.08$ & $15.04 \pm 0.05$ & $15.10 \pm 0.06$ & $15.10 \pm 0.07$ & $15.17 \pm 0.11$ \\
\hline PCT (\%) & $0.39 \pm 0.04$ & $0.29 \pm 0.05^{\mathrm{b}}$ & $0.42 \pm 0.03$ & $0.42 \pm 0.01^{\mathrm{a}}$ & $0.41 \pm 0.03$ & $0.34 \pm 0.02^{\mathrm{ab}}$ \\
\hline $\mathrm{WBC}\left(\mathrm{x} 10^{9} / \mathrm{L}\right)$ & $5.23 \pm 0.57$ & $5.19 \pm 0.62$ & $6.74 \pm 0.98$ & $5.16 \pm 1.03$ & $6.91 \pm 1.90$ & $5.06 \pm 1.11$ \\
\hline Lymphocyte $\left(\mathrm{x} 10^{9} / \mathrm{L}\right)$ & $3.73 \pm 0.47$ & $3.77 \pm 0.45$ & $4.69 \pm 0.73$ & $3.50 \pm 0.72$ & $4.77 \pm 1.49$ & $3.10 \pm 0.72$ \\
\hline Monocyte (x10 $10^{9}$ ) & $0.13 \pm 0.02$ & $0.14 \pm 0.02$ & $0.19 \pm 0.04$ & $0.10 \pm 0.02$ & $0.16 \pm 0.05$ & $0.11 \pm 0.03$ \\
\hline Granulocyte $\left(\times 10^{9} / \mathrm{L}\right)$ & $1.37 \pm 0.19$ & $1.27 \pm 0.18$ & $1.87 \pm 0.29$ & $1.56 \pm 0.44$ & $1.99 \pm 0.49$ & $1.84 \pm 0.44$ \\
\hline Lymphocyte (\%) & $71.20 \pm 3.12$ & $73.29 \pm 1.71^{\mathrm{a}}$ & $69.34 \pm 3.47$ & $66.47 \pm 4.04^{\mathrm{ab}}$ & $65.89 \pm 3.63$ & $61.17 \pm 2.46^{\mathrm{b}}$ \\
\hline Monocyte (\%) & $2.31 \pm 0.16^{\mathrm{b}}$ & $2.76 \pm 0.19$ & $3.07 \pm 0.32^{\mathrm{a}}$ & $2.40 \pm 0.12$ & $2.53 \pm 0.18^{\mathrm{ab}}$ & $2.34 \pm 0.22$ \\
\hline Granulocyte (\%) & $26.49 \pm 3.14$ & $24.39 \pm 1.55^{\mathrm{b}}$ & $27.59 \pm 3.26$ & $31.13 \pm 4.00^{\mathrm{ab}}$ & $31.59 \pm 3.59$ & $36.49 \pm 2.38^{\mathrm{a}}$ \\
\hline
\end{tabular}

a,b,c: Different letters shown the statistical significance among the groups on the same weeks $(\mathrm{p}<0.05)$.

$(*)$ : Sign shown statistical significance among the weeks in the same groups $(\mathrm{p}<0.05)$.

a,b,c: Farklı harfler, aynı haftadaki gruplar arası farklılıkları göstermektedir $(\mathrm{p}<0.05)$.

$(*)$ : Sembol, aynı gruptaki haftalar arası farklılıkları göstermektedir $(\mathrm{p}<0.05)$.

\section{Discussion and Conclusion}

In accordance with the report of Bianco et al. (2), PTU and L-T4 could be used via orally into drinking water to realize systemic hypothyroidism and hyperthyroidism experimentally in rodents. Although, in order to achieve hypothyroidism and hyperthyroidism by oral administration has less effective than daily injections and requires much longer treatment duration, it reduces the occurrence of the vast diurnal changes in plasma hormone concentrations which is regarded as an advantage (14). In this regard, this study was carried out to interpretation effects of thyroid alterations on the hematological parameters throughout different exposure times. In the present study, altered TSH, TT4 and FT4 levels on 3rd and 6th weeks have shown that hypothyroidism and hyperthyroidism have been well established in experimental groups in parallel with previous studies $(21,33)$.

According to our results, the RBC counts were increased in the 6th week euthyroid group compared to the 3rd week euthyroid group. These results are in agreement with previous studies $(12,18)$ which were explained by age dependent changes in rats.

Hypothyroidism could cause certain forms of anemia in humans (3) and various animals as dogs (6), rabbits (17), ewes (27) and rats (35). Several reports have 
concluded that thionamide based antithyroid agents such as PTU and methimazole (MMI) could reduce RBC counts, Hct value and $\mathrm{Hb}$ concentrations by adverse suppressive effects on bone marrow $(26,28)$. Nambiar et al. (28) indicated that the reduction of erythrocyte parameters is related with dose dependent manner in rats. Likewise, Jawad and Atyaf (17) exhibited similar results based on dose-dependent effect of hypothyroidism in rabbits. In accordance with our findings, although the changes in the RBC counts, Hct value, Hb concentration and percentage of RDW were not important in the 3rd week hypothyroidism group when compared to the euthyroid group, the cause of significantly decrease in the same hematological values in the 6th week hypothyroid group might be progression of hypothyroidism depend on treatment duration. However, these statistical significance results were within normal physiological ranges for rats (12).

Hyperthyroidism, which has been known as a cause of erythrocytosis, could be explained by two ways; firstly, enhanced production of Epo from kidney (9) and secondly, direct effect on bone marrow by modifiy gene expressions of TRs (19). Zahediasl et al. (40) reported that in the 30 and 60 days hyperthyroid rats were not observed significant differences in the RBC counts. On the other hand, $\mathrm{Hb}$ concentration, Hct value, mean corpuscular hemoglobin $(\mathrm{MCH})$ and mean corpuscular volume (MCV) levels in the 60 days treated hyperthyroid group was significantly higher compared to control group. In contrast, Messarah et al. (25) noted that the $\mathrm{RBC}$ counts, Hct value and $\mathrm{Hb}$ concentrations were decreased in the L-T4 treated rats during 5 weeks. These contrary findings in the literature can be explained by enhanced lipid peroxidation due to increased basal metabolic rate throughout hyperthyroidism $(14,25)$. Yücel et al. (39) reported that L-thyroxine administration in rats for 30 days may enhanced susceptibility of erythrocytes due to raising the levels of lipid peroxidation and their last products such as malondialdehyde. These circumstances, may led to increase in osmotic fragility of erythrocytes and hemolysis. According to our results, statistical differences were not found in the erythrocyte parameters neither in the 3rd nor in the 6th week hyperthyroid groups compared to the euthyroid groups.

Hypothyroidism and hyperthyroidism may be linked with some hemostatic abnormalities (24). In the present study, PLT, mean platelet volume (MPV), platelet distribution width (PDW) or PCT counts were not changed in the 3rd week treated groups. However, PLT counts were found higher in the 6th week hypothyroid group. Furthermore, it was decreased in the 6th week hyperthyroid group when compared to the $3 \mathrm{rd}$ week hyperthyroid and the 6th week hypothyroid groups. In parallel with our results, Sullivan and McDonald (34) reported that both $\mathrm{D}$ - and L- thyroxine administration in mice caused the decrease in peripheral platelet count, total circulating platelet count and mass due to depressed platelet production. In another study, Dönmez and Keskin (7) interpreted that the increase in platelet counts could cause as a regenerative response of bleeding tendency. Platelet aggregation is associated with platelet counts (37). Moreover, platelet aggregation is inversely correlated with thyroid hormone concentration (29). Nejar Bruno et al. (29) reported that 5'-nucleotidase activity in platelets which enzyme caused degradation of adenosine monophosphate to adenosine were increased in the hypothyroid and decreased in the hyperthyroid rats. The results indicate that altered platelet 5'-nucleotidase activity during hypo- and hyperthyroidism could led to changes in adenosine levels and consequently influenced the platelet aggregation.

In the present study, PTU and L-T4 treatment did not affect the leucocyte counts significantly. On the other hand, in the 3rd week hypothyroid group percentage of monocyte increased and in the 6th week hyperthyroid group percentage of lymphocyte decreased and percentage of granulocyte increased when compared to their euthyroid controls. On contrary to our findings, Abou-auda and Abou-shaaban (1) reported that PTU induced hypothyroidism during 30 days period decreased the percentage of monocyte in rats. In another study, Nambiar et al. (28) noted that white blood cell (WBC), lymphocyte and monocyte counts were decreased by different dosage regimens in PTU treated rats. Moreover, Osonuga et al. (32) noted that L-T4 administration for 28 days in rats decreased WBC counts.

In conclusion, the present study showed that experimentally induced hypothyroidism and hyperthyroidism could not change the hematological parameters except percentage of monocytes throughout 3 week. However, even if these values remained within physiological ranges, elongation of the treatment duration with PTU to 6 week could lead to changes on RBC counts, $\mathrm{Hb}$ concentration, Hct, RDW and PCT values. Moreover, L-T4 administration could cause changes on $\mathrm{MHCH}$ and PLT counts significantly.

\section{Acknowledgement}

This study was partially supported by Selçuk University Scientific Research Projects Coordination Unit (Project No: SUBAP-12102019).

\section{References}

1. Abou-auda HS, Abou-shaaban RRA (2006): Effect of abouthiouline a novel drug with therapeutic potential as antithyroid, on some biochemical and hematologic parameters in mice and rats. Saudi Pharm J, 14, 34-41.

2. Bianco AC, Anderson G, Forrest D, et al. (2014): American Thyroid Association Guide to investigating 
thyroid hormone economy and action in rodent and cell models. Thyroid, 24, 88-168.

3. Chandel RS, Gangadhar C, Leela A (2015): Impact of subclinical hypothyroidism on iron status and hematological parameters. APALM, 2, 21-25.

4. Das K, Chainy GBN (2004): Thyroid hormone influences antioxidant defense system in adult rat brain. Neurochem Res, 29, 1755-1766.

5. Davis PJ, Leonard JL, Davis FB (2008): Mechanisms of nongenomic actions of thyroid hormone. Front Neuroendocrinol, 29, 211-218.

6. Dixon RM, Reid SW, Mooney CT (1999): Epidemiological, clinical, haematological and biochemical characteristics of canine hypothyroidism. Vet Rec, 145, 481-487.

7. Dönmez N, Keskin E (2009): The effects of aflatoxin and glucomannan on coagulation parameters in rabbits. Veterinarski Arhiv, 79, 555-560.

8. El-Bakry AM, El-Gareib AW, Ahmed RG (2010): Comparative study of the effects of experimentally induced hypothyroidism and hyperthyroidism in some brain regions in albino rats. Int J Dev Neurosci, 28, 371-389.

9. Fandrey J, Pagel H, Frede S, et al. (1994): Thyroid hormones enhance hypoxia-induced erythropoietin production in vitro. Exp Hematol, 22, 272-277.

10. Ferreira E, Silva AE, Serakides R, et al. (2007): Model of induction of thyroid dysfunctions in adult female mice. Arq Bras Med Vet Zootec, 59, 1245-1249.

11. Flamant F, Baxter JD, Forrest D, et al. (2006): International Union of Pharmacology. LIX. The pharmacology and classification of the nuclear receptor superfamily: Thyroid hormone receptors. Pharmacol Rev, 58, 705-711.

12. Giknis MLA, Clifford CB (2008): Clinical Laboratory Parameters for Crl:Wl (Han). http://www.criver.com/files/pdfs/rms/wistarhan/rm_rm_r_ wistar_han_clin_lab_parameters_08.aspx.(20.03.2015)

13. Golde D W, Bersch N, Chopra IJ, et al. (1977): Thyroid hormones stimulate erythropoiesis in vitro. Br J Haematol, 37, 173-177.

14. Guerrero A, Pamplona R, Portero-Otin M, et al. (1999): Effect of thyroid status on lipid composition and peroxidation in the mouse liver. Free Radic Biol Med, 26, 73-80.

15. Guyton AC, Hall JE (2011): Thyroid Metabolic Hormones. 931-943. In: Guyton and Hall Textbook of Medical Physiology, Elsevier, United States of America,.

16. Hulbert AJ (2000): Thyroid hormones and their effects: A new perspective. Biological Reviews, 75, 519-631.

17. Jawad KA, Atyaf JHA-Z (2015): The therapeutic role of alcoholic extract of fenugreek seeds on hypothyroidism state induced by thiourea and some blood parameters in adult male rabbits. The Iraqi J Vet Med, 39, 1-7.

18. Kampfmann I, Bauer N, Johannes S, et al. (2012): Differences in hematologic variables in rats of the same strain but different origin. Vet Clin Pathol, 41, 228-234.

19. Kawa MP, Grymula K, Paczkowska E, et al. (2010): Clinical relevance of thyroid dysfunction in human haematopoiesis: biochemical and molecular studies. Eur J Endocrinol, 162, 295-305.
20. Kendrick TS, Payne CJ, Epis MR, et al. (2008): Erythroid defects in TRalpha-/- mice. Blood, 111, 32453248.

21. Klecha AJ, Genaro AM, Gorelik G, et al. (2006): Integrative study of hypothalamus-pituitary-thyroidimmune system interaction: Thyroid hormone-mediated modulation of lymphocyte activity through the protein kinase C signaling pathway. J Endocrinol, 189, 45-55.

22. Malgor LA, Blanc CC, Klainer E et al. (1975): Direct effects of thyroid hormones on bone marrow erythroid cells of rats. Blood, 45, 671-679.

23. Manna D, Roy G, Mugesh G (2013): Antithyroid drugs and their analogues: Synthesis, structure, and mechanism of action. Accounts of Chemical Research, 46, 2706-2715.

24. Marongiu F, Barcellona D, Mameli A et al. (2011): Thyroid disorders and hypocoagulability. Semin Thromb Hemost, 37, 11-16.

25. Messarah M, Saoudi M, Boumendjel A, et al. (2011): Oxidative stress induced by thyroid dysfunction in rat erythrocytes and heart. Environ Toxicol Pharmacol, 31, 33-41.

26. Moriyama K, Tagami T, Usui T, et al. (2007): Antithyroid drugs inhibit thyroid hormone receptormediated transcription. J Clin Endocrinol Metab, 92, 1066-1072.

27. Mostaghni K, Bashari Maafi A, Badiei K (2005): Study of the effects of experimental hypothyroidism on clinical, hematological and serum biochemical factors in pregnant ewes. Iran J Vet Res, 6, 1-5, 73.

28. Nambiar PR, Palanisamy GS, Okerberg C, et al. (2014): Toxicities associated with 1-month treatment with propylthiouracil (PTU) and methimazole (MMI) in male rats. Toxicol Pathol, 42, 970-983.

29. Nejar Bruno A, Pochmann D, Klein Ricachenevsky F, et al. (2005): 5'-nucleotidase activity is altered by hypoand hyperthyroidism in platelets from adult rats. Platelets, 16, 25-30.

30. Noyan A (2011): Tiroid Bezi ve Hormonu. 1007-1033. In: Yaşamda ve Hekimlikte Fizyoloji, Palme Yayınları, Ankara.

31. Oetting A, Yen PM (2007): New insights into thyroid hormone action. Best Pract Res Clin Endocrinol Metab, 21, 193-208.

32. Osonuga IO, Olowookorun MO, Akinola BO (2014): Effects of thyroxine on blood parameters and liver enzymes in adult male and female rats. Afr J Biomed Res, 17, 53-56.

33. Serakides R, Ocarino NM, Cardoso TGS, et al. (2005): Response of parathyroid to the plasmatic of calcium and phosphorus variations in hyperthyroidism and hypogonadism in the rat. Arq Bras Med Vet Zootec, 57, 48-54.

34. Sullivan PS, McDonald TP (1992): Thyroxine suppresses thrombocytopoiesis and stimulates erythropoiesis in mice. Proc Soc Exp Biol Med, 201, 271-277.

35. Umezu M, Kagabu S, Jiang J, et al. (1998): Evaluation and characterization of congenital hypothyroidism in $r d w$ dwarf rats. Lab Anim Sci, 48, 496-501.

36. Vennström B, Liu H, Forrest D (2010): Thyroid hormone receptors. 183-201 In: Chris M. Bunce MJC (Ed) Nuclear Receptors Current Consepts and Future Challenges. Springer, Netherlands. 
37. Würtz M, Hvas AM, Kristensen SD, et al. (2012): Platelet aggregation is dependent on platelet count in patients with coronary artery disease. Thromb Res, 129, 56-61.

38. Yen PM (2001): Physiological and molecular basis of thyroid hormone action. Physiol Rev, 81, 1097-1142.

39. Yücel R, Özdemir S, Darıyerli N, et al. (2009): Erythrocyte osmotic fragility and lipid peroxidation in experimental hyperthyroidism. Endocr, 36, 498-502.

40. Zahediasl S, Habibi G, Ghasemi A, et al. (2010): Hematological parameters and osmotic fragility of red blood cells in experimentally induced hyperthyroidism in rats. Int J Endocrinol Metab, 8, 74-78.
Geliş tarihi: 03.09.2015 / Kabul tarihi: 30.11.2015

\section{Address for correspondence:}

Arş. Gör. Sinan KANDIR

Selçuk University, Faculty of Veterinary Medicine,

Department of Physiology, 42075,

Konya/TURKEY

e-mail: skandir@selcuk.edu.tr 